\title{
Analysis of Factors Affecting Application of Computer-Based Accounting Information System on Banking Sector
}

\author{
Siti Nur Azizah \\ Universitas Muhammadiyah Purwokerto \\ sitinurazizah@ump.ac.id
}

\begin{abstract}
This study aims to analyze user participation factor, the ability of individual's techniques, training and education programs, the support of top management, the quality of information, perceived benefits and perceived ease toward user satisfaction. This research method is a quantitative survey using purposive sampling on internal side such as employee's perspective through questionnaires, which are distributed to employees in all branches of the Central Java Bank both conventional and Islamic. This study uses Technology Acceptance Model (TAM) to measure the level of user satisfaction of the system of psychological factors and types of banks as control variables in research. The results of this study reveal that user satisfaction of information systems in Central Java Bank affected by two factors, namely the ability of individual techniques and top management support.
\end{abstract}

Keywords: TAM and Banking Information System

\section{INTRODUCTION}

Bank is one of the financial institutions that collects funds from people who own more fund to lend to people who lack of fund and other services to get mutual benefits. The development of the banking industry is influenced by several factors, one of which is the political factor of government. Government policies impact on the growth of the banking industry, so banks must follow the policy both domestic and foreign.

To address the negative impacts of policies in the current globalization era, a business entity especially banking is required to develop the business to improve its competitiveness. Moreover, the utilization of information technology in the business sector is rapidly growing, so that a business entity is urged to apply technology and information systems to process and produce effective and efficient information in order to support business service quality.

A bank used to study in this research project is the Central Java Bank. During Indonesia Banking Award competition in 2015, Central Java Bank is recorded to have weakness in its digital services category, so considered as inadequate (bisnis.tempo.co). As regional development banks on the biggest island of Indonesia but its digital system is not optimized yet has led Central Java Bank as interesting object to be examined in their usage of the system.

Training and education have a positive effect on user satisfaction of information system [1]-[2]. Another relevant research proves that there is no influence between training and user satisfaction of information systems [3].

In previous research on several banks in Indonesia showed different results. PT. Bank Muamalat shows that there is no significant influence on users' engagement factors on user satisfaction of the system. Also, it is pointed out that the factors of department location, training, and education also have no effect on system user satisfaction at PT. Bank Muamalat [4] . This is in line with research on Government Banks in a wider scope [5].

On the contrary, banking in Yogyakarta Special Region shows result that user involvement become the influencing factor to user's satisfaction of the system [6]. In addition, another relevant research proves that individual's positve support affects user's satisfaction of accounting information system performance in the company [7]. The results of this study are supported by research on the implementation of Internet Banking in Iran which reveals that user's involvement affects user's satisfaction of accounting information system performance [8]. Another relevant research also adds user training and education program factors as well as the results showing the effect on user's satisfaction of accounting information system [9]. Based on the existence of several different gaps of similar research results on some of the past studies and problems occurring in some of Central Java Bank Branches, it is necessary to investigate further with a wider scope in all branches of Central Java banks.

Theory Acceptance Model (TAM) was first introduced in 1986 [10]. This TAM is the development of Theory of Reasoned Action (TRA), a model of technology acceptance assessment that identifies the level of individual's acceptance of a technology. The TAM analysis developed by Davis is one of the most widely used models in information technology research [11]-[13]. This technology is used in the banking system in many versions, one of which is greenscreen. Greenscreen is a computer-based accounting information system implemented by Central Java Bank that is used to process financial and non financial transaction data.

\section{METHOD}

This research was categorized as quantitative research conducted by a survey method in branch offices 
of Central Java Bank. The object of this research is user satisfaction of computer-based accounting information system in Central Java Bank. One method used to determine the number of samples is the use of the Slovin [8].

Data obtained from human resources database at the Central Java Bank Head Office stated that the total number of executing personnel recorded on December 2015 was 815 employees. Based on the Slovin formula, with a population of 815 and a $5 \%$ error limit then it can be calculated around 269 employees. This research used the multiple regression and simple regression analysis to analyze the influence of the independent variables on the dependent variables [14].

\section{RESULT}

Hypothesis 1 states the ability of individual's techniques have positive effect on user's satisfaction of accounting information system, so hypothesis 1 is accepted.

According to the theory proposed, in general, the more individuals have the ability or competence related to the system, they will be more satisfied in using the system [15]. This happens because the placement of personnel in a position is primarily concerned with educational background and previous experience. This is applied to reduce perceptual differences between information display in the system and user perceptions. For example, in the division of analyst and credit / finance admin are not recommended to be managed by any individuals who does not meet the competency standards and experience. This position must be performed by competent personnel who is professional in financial statements and detail in charging data related to debt / credit between companies and third parties. This issue is highly concerned by the company because in addition to this position has an impact in the long term, credit is also a major source of income of the company.

The results of this study are consistent with some studies [15], [4], [8], [16] and [17]. However, this result is also inconsistent with some studies [18]-[19].

Hypothesis 2 states that training and education programs have positive effect on user's satisfaction of accounting information system. Based on the theory, put forward training programs and system education affect user satisfaction system [20]. The result shows factor of training and education programs have no effect on user satisfaction of accounting information system and hypothesis 2 is rejected.

Basically, the training and education program of a system is to reduce human error related to the use of the system so as to increase the user satisfaction of the system itself. But in fact, the educational materials and training are only theoretically delivered so that not applicable work and does not correspond to the real ciscusmtances in the field. In addition, content of the material delivered is often the same and repeated of the previous training. Thus, it becomes meaningless and not significant for trainees and educators. So the results of research to prove that training and education programs held by the company does not have influence on user satisfaction system.

The results of this study are consistent with researchers who found evidence that training and education programs had no significant effect on system of user satisfaction [1]-[2]. However, the results of this study are inconsistent with other relevant studies which proves that training and education affect satisfaction [21]-[22].

Hypothesis 3 states that top management positive support affect the user satisfaction of accounting information systems. In the theory proposed, top management support has positive influence on the satisfaction of information system performance [23]. The result shows that top management support has positive influence on user satisfaction of accounting information system so that hypothesis 4 is accepted. That is, the higher form of support from top management, the higher user satisfaction of accounting information system will be. This is because top management or superiors have experience in the fields and really understand the system used everyday well.

$$
\begin{gathered}
Y=a+b 1 X 1+b 2 X 2+b 3 X 3+b 4 X 4+b 5 X 5+b 6 \times 6+ \\
b 7 X 7+b 8 X 8+e
\end{gathered}
$$

Table 1. Hypothesis Testing Result

\begin{tabular}{lccll} 
Hypothesis & Beta & Sig & Conclusion & Effect \\
\hline H1 (Engineering Capability) & 0.344 & 0.036 & Accepted & Positive \\
H2(Training and Education Program) & -0.032 & 0.395 & Rejected & - \\
H3 (Management's Support) & 0.037 & 0.033 & Accepted & Positive \\
\hline
\end{tabular}

The management of the company meant in the branch office is the branch leader and the branch representative, then in one branch office each consisting of 2 top management. So in some cases, management board is not only responsible for the office alone, but it is important that the management can directly monitor the performance in the field. This can be used by management as the basis for decision making because management participates in direct activities in the field so that the management really knows in certain about the situation.

In some operations, management is often included in direct activities such as field surveys and direct interviews to third parties until third party record also 
requires management to participate. It aims to teach junior personnel how to handle large amounts of credit and share experiences between senior and junior.

The role of top management to look after the operational and non-operational activities every day so that each individual must always report operational activities in the field periodically to management. It is very demanding that the role of top management in directing and resolving problems arised through joint discussion. Thus, the role and support of top management have a positive effect on user satisfaction of accounting information system. The results of this study are consistent with some studies [23], [24], [25], [26] but inconsistent with other studies [1], [27] and [9]..

\section{CONCLUSION}

Based on the empirical evidence obtained, it is concluded that the ability of individual techniques and top management's support have positive effect on user satisfaction of accounting information system wheareas training and education programs does not.

\section{REFERENCES}

[1] Bradford, M. \& Florin, J. 2003 , "Examining the role of innovation diffusion factors on the implementation success of enterprise resource planning systems", International journal of Accounting Information Systems, Vol. 4, pp. 205225.

[2] Dezdar, S., \& Ainin, S. 2011. The influence of organizational factors on successful ERP implementation. Management Decision, Vol.49, No.6, pp. 91-926.

[3] Divyaranjani, DDR R.Rajasekar. 2012. A study on job satisfaction before and after training and development programme. International journal of Research in Management and Business studies ISSN : 2348-6503.

[4] Septriani, Evy. 2010. Pengaruh Kinerja Sistem Terhadap Kepuasan Pengguna Pada PT.Bank Muamalat Indonesia (Tbk). Program Magister Sistem Informasi Akuntansi. Universitas Gunadarma.

[5] Sahusilawane, Wildoms. 2014. Pengaruh partisipasi pemakai dan dukungan atasan terhadap kinerja sia pada Bank Umum Pemerintah. Universitas Terbuka.

[6] Kusuma, Hadri .2007. Determinan Pengadopsian Layanan Internet Banking: Perspektif konsumen Perbankan Daerah Istimewa Yogyakarta. Jurnal Auditing dan Akuntansi Indonesia. Vol. 12 no 1, 2007.

[7] Al-Somali, S. A., Gholami, R., \& Clegg, B. 2008. Internet Banking Acceptance in the Context of Developing Countries : An Extension of the Technology Acceptance Model. European Conference on Management of Technology . Vol 12 no 9.

[8] Amini, M., T., Ahmadinejad, M. Azizi, M., J. 2011. Adoption of Internet Banking By Iranian Customer:
An Empirical Investigation. The International Journal Of Management Science And Information Technology (Ijmist), I(1), 47-64.

[9] Gustiyan, Harry. 2014. Analisis faktor-faktor yang mempengaruhi SIA pada BPR di Tanjungpinang. Universitas Maritim Raja Ali Haji Tanjungpinang.

[10] Davis D., 1989. Perceived Usefulness, Perceived Ease of Use, and User Acceptance of Information Technology. Computer Journal of MIS Quarterly, vol. 13, no. 3, pp. 319-340.

[11] Davis D., Bagozzi P., \& Warshaw R., 1989. User Acceptance of Computer Technology: A Comparison of Two Theoretical Models. Computer Journal of Management Science, vol. 35, no. 8, pp. 982-1003.

[12] Davis D., Bagozzi P., \& Warshaw R., 1992. Extrinsic and Intrinsic Motivation to Use Computers in the Workplace. Journal of Applied Social Psychology, vol. 22, no. 14, pp. 1111-1132.

[13] Venkatesh, V. \& Davis, F.D. 2000. A Theoretical Extension of the Technology Acceptance Model: Four Longitudinal Field Studies, Management Science, 46, 2000, 186-204.

[14] Suliyanto. 2011. Ekonometrika Terapan: Teori dan Aplikasi dengan SPSS. Yogyakarta: ANDI.

[15] Tan, Margaret. 2000. Factors Influencing the Adoption of Internet Banking. Journal of the Association for Information Systems. National University of Singapore.

[16] Park, S., \& Zo, H., \& Ciganek, A.P., \& Lim, G.G. 2011. Examining success factors in the adoption of digital object identifier systems. Electronic Commerce Research and Applications, vol.10, pp. 626-636.

[17] Urbach, N., \& Smolnik, S., \& Riempp, G. 2011. Determining the improvement potentials of employee portals using a performance-based analysis, Business Process Management Journal Vol. 17, No. 5, pp. 829-845.

[18] Awamleh J. \& Mahate A., 2003. Internet Banking in Emergency Markets: The Case of Jordan - A Note, Computer Journal of Internet Banking and Commerce, vol. 8, no.1, pp. 41-62, 2003.

[19] Sari, Niki Puspita, Armanu Thoyib, Noermijati. 2014. The Effect of Perceived Organizational Support and Job Satisfaction toward Organizational Citizenship Behavior Mediated By Organizational Commitment (A Study on Teachers of Islamic Boarding High School in Tulungagung Regency). International Journal of Business and Behavioral Sciences Vol. 4, No.2.

[20] Abu Shanab E., Md K., Pearson M., \& Crosby L., 2003. Self-Efficacy and End User Satisfaction: The Impact of Social Influence, in Proceedings of the Decision Sciences Institute Conference Washington DC, pp. 1-6, 2003.

[21] Komara, Acep. 2006. Analisis Faktor-Faktor yang Mempengaruhi Kinerja Sistem Informasi Akuntansi. Jurnal Maksi Vol.6 No.2. Hal.143-260.

[22] Srimindarti, Ceacilia \& Elen Puspitasari. 2012. 
Kinerja Sistem Informasi Akuntansi Ditinjau dari Kepuasan Pemakai dan Pemakaian Sistem Informasi Akuntansi yang Dipengaruhi oleh Partisipasi, Kemampuan, Pelatihan dan Pendidikan Pemakai Sistem Informasi Akuntansi. Jurnal Pekan Ilmiah Dosen FEB-UKSW

[23] Calantone, R. J., David A Griffith dan Goksel Yalcinkaya. 2006. An Empirical Examination of a Technology Adoption for the Context of China. Journal of International Marketing, 14 (4), pp.1-27, 2006.

[24] Cho, V. 2007. A Study of the Impact of Organizational Learning On Information System Effectiveness. International Journal of Business and Information, Volume 2, Number 1,pp.127-158.
[25] Tangke, Natalia. 2004. Analisa Penerimaan Penerapan Teknik Audit Berbantuan Komputer (TABK) dengan Menggunakan Technology Acceptance Model (TAM) pada Badan Pemeriksa Keuangan (BPK) RI. Jurnal Akuntansi \& Keuangan Vol. 6 No. 1, Mei $2004: 10-8$.

[26] Halawi, L. A., Mccarthy, R. V., \& Aronson, J. E. 2008. An Empirical Investigation of Knowledge Management Systems success. Journal of Computer Information Systems, pp. 121-136.

[27] Armitage J. \& Conner M., 2001. Efficacy of the Theory of Planned Behavior: A Meta-Analytic Review, Computer Journal of British Journal of Social Psychology, vol. 40, no. 4, pp. 471-499, 2001. 